\title{
Application of Indoor Recirculation Aquaculture System for White Shrimp (Litopenaeus vannamei) Growout Super-Intensive Culture at Low Salinity Condition
}

\author{
Gede Suantika $^{1 *}$, Magdalena Lenny Situmorang ${ }^{1}$, Adani Nurfathurahmi ${ }^{1}$, Intan Taufik ${ }^{1}$, Pingkan Aditiawati ${ }^{1}$, Nasukha Yusuf ${ }^{2}$ and Rizkiyanti \\ Aulia ${ }^{2}$ \\ ${ }^{1}$ Microbial Biotechnology Research Group, School of Life Sciences and Technology, Institut Teknologi Bandung, Bandung, Indonesia \\ ${ }^{2}$ Biology Study Program, School of Life Sciences and Technology, Institut Teknologi Bandung, Bandung, Indonesia
}

\begin{abstract}
The use of close aquaculture system including Recirculation Aquaculture System (RAS) has been implemented to allow a more stable water quality, good hygiene and efficient use of water resources in wide shrimp aquaculture production. This study aims to optimize shrimp stocking density and to evaluate microbial community profile in super-intensive culture of Pacific white shrimp (Litopenaeus vannamei) using RAS technology at low salinity. Before stocking, post larvae shrimp was gradually acclimatized from salinity level of 32 ppt to 5 ppt within 14 days. Different stocking density of $500 \mathrm{PL} / \mathrm{m}^{3}, 750 \mathrm{PL} / \mathrm{m}^{3}$ and $1,000 \mathrm{PL} / \mathrm{m}^{3}$ were tested in four replicates. During 84 days grow out period, no differences in water quality parameters were observed. At the end of grow out period, significant differences were found in final body weight $(14.87 \pm 0.24 \mathrm{~g}, 13.09 \pm 0.78 \mathrm{~g}, 11.32 \pm 0.71 \mathrm{~g})$, survival $(70 \pm 1.42 \%, 53.67 \pm 4.16 \%$, $44 \pm 1.35 \%)$, specific growth rate $(7.12 \% \mathrm{BW} /$ day, $6.95 \% \mathrm{BW} /$ day, $6.79 \% \mathrm{BW} /$ day), and feed conversion ratio $(1.32$ $\pm 0.09,1.45 \pm 0.16,2.05 \pm 0.24$ ) for the $500 \mathrm{PL} / \mathrm{m}^{3}, 750 \mathrm{PL} / \mathrm{m}^{3}$, and $1,000 \mathrm{PL} / \mathrm{m}^{3}$ treatment group, respectively. However, similar total productivity of $5.20 \mathrm{~kg} / \mathrm{m}^{3}, 5.24 \mathrm{~kg} / \mathrm{m}^{3}$, and $4.99 \mathrm{~kg} / \mathrm{m}^{3}$ was observed for $500 \mathrm{PL} / \mathrm{m}^{3}, 750 \mathrm{PL} / \mathrm{m}^{3}$, and $1,000 \mathrm{PL} / \mathrm{m}^{3}$ treatment group, respectively. The implementation of RAS can allow a stable community structure of culturable bacteria even at high shrimp density of up to $1,000 \mathrm{PL} / \mathrm{m}^{3}$, with the observed bacterial abundance of $1.28 \times 10^{3}$ to $5.28 \times 10^{4} \mathrm{CFU} / \mathrm{mL}$ and $9.49 \times 10^{4}$ to $2.27 \times 10^{6} \mathrm{CFU} / \mathrm{mL}$ in shrimp and culture water, respectively. It is suggested that the application of RAS at the optimal shrimp density of $500 \mathrm{PL} / \mathrm{m}^{3}$ allowed a high shrimp culture productivity of up to $5.20 \mathrm{~kg} / \mathrm{m}^{3}$ within 84 days grow out period.
\end{abstract}

Keywords: Litopenaeus vannamei; Culturable bacteria; Community structure; Low salinity; Recirculation aquaculture system; Stocking density

\section{Introduction}

Indonesia is the largest archipelagic country in the world with 5.8 million $\mathrm{km}^{2}$ of ocean and $91,181 \mathrm{~km}$ of coastline, which contain marine and fishery resources as potential for natural resource-based economic development [1]. Recently, Indonesia is world's second largest aquaculture producer country after China. In average, the aquaculture production in Indonesia increased $27.8 \%$ per year [2], where $16.5 \%$ of the total production are dominate by shrimp industry. Pacific white shrimp, Litopenaeus vannamei, is one of the main commodities [2] due to the availability of its Specific Pathogen Free (SPF) broodstock/larvae [3] as well as its ability to grow in high stocking densities and cope with wide variations of water salinity [4]. Even though the global farmed shrimp production has increased in the recent years, major producing countries has experienced a decline in output due to disease-related problems including vibriosis caused by pathogenic bacteria Vibrio sp. It has been suggested that the number of Vibrio sp. which exceeds the threshold of $10^{4} \mathrm{CFU} / \mathrm{mL}$ indicating susceptibility to vibriosis. Vibriosis often occurred when the organic content in the pond is high. Therefore, maintenance of water quality is critical in wide shrimp production [5].

Conventional improvement of shrimp production through the expansion of land and use of open systems has several constraints including unstable water quality and high susceptibility to infectious diseases that often lead to the unpredicted shrimp productivity. On the other hand, the use of close system Recirculation Aquaculture System (RAS) offers a more flexible, predictable, hygienic, and environmentally friendly shrimp production even at high density, contributing to the more sustainable shrimp industry [6]. RAS technology has the advantage of highly efficient use of water resources, mainly due to the water treatment process through water circulation along the RAS components. It is also including physical and biological filtration units, which can solve the problems raised from high level of organic content in the system and also minimize the risk of infection by pathogenic bacteria that may exist in new untreated seawater [6].

Related to the disease problem, one alternative strategy to address the vibriosis problem has been provided in the form of the bacterial storage compound poly- $\beta$-hydroxybutyrate $(\mathrm{PHB})$, the polymer of the short-chain fatty acid $\beta$-hydroxybutyrate $(\beta-\mathrm{HB})$, as carbon reserve and intracellular energy source for a large variety of bacteria, including the genera of Bacillus, Pseudomonas, Rhizobium and Alcaligenes. PHB is water insoluble and biologically degrades into b-HB upon entrance in the gastrointestinal tract [7]. Several studies have confirmed the protective effect of $\mathrm{PHB}$ against a variety of bacterial diseases in farmed aquatic animals against, albeit through undefined mechanisms [8-11]. Interestingly enough, an increased growth performance in crustaceans has also been observed as a result of dietary PHB supplementation for prawn $[9,12]$ and shrimp [13] culture. Therefore, this study aims to

*Corresponding author: Gede Suantika, Microbial Biotechnology Research Group, School of Life Sciences and Technology, Institut Teknologi Bandung Jalan Ganesha No. 10, Bandung-40132, Indonesia, Tel: +62 222511575 E-mail: gsuantika@sith.itb.ac.id

Received March 28, 2018; Accepted April 20, 2018; Published April 25, 2018

Citation: Suantika G, Situmorang ML, Nurfathurahmi A, Taufik I, Aditiawati P, et al. (2018) Application of Indoor Recirculation Aquaculture System for White Shrimp (Litopenaeus vannamei) Growout Super-Intensive Culture at Low Salinity Condition. J Aquac Res Development 9: 530. doi: 10.4172/2155-9546.1000530

Copyright: (c) 2018 Suantika G, et al. This is an open-access article distributed under the terms of the Creative Commons Attribution License, which permits unrestricted use, distribution, and reproduction in any medium, provided the original author and source are credited. 
Citation: Suantika G, Situmorang ML, Nurfathurahmi A, Taufik I, Aditiawati P, et al. (2018) Application of Indoor Recirculation Aquaculture System for White Shrimp (Litopenaeus vannamei) Growout Super-Intensive Culture at Low Salinity Condition. J Aquac Res Development 9: 530. doi: 10.4172/2155-9546.1000530

Page 2 of 6

optimize the stocking density and to evaluate community structure of culturable bacteria in super-intensive culture of Pacific white shrimp (Litopenaeus vannamei) fed with PHB supplemented diet in RAS technology at low salinity condition.

\section{Materials and Methods}

\section{System preparation and conditioning}

This study was took place at the Laboratory of Aquatic Ecology, School of Life Sciences and Technology, Institut Teknologi Bandung. The RAS system consists of $100 \mathrm{~L}$ settlement tank, $100 \mathrm{~L}$ protein skimmer, $50 \mathrm{~L}$ activated carbon tank, $300 \mathrm{~L}$ biofilter and 12 of $100 \mathrm{~L}$ shrimp culture tanks (Figure 1). Following the inoculation of nitrifying bacteria consortium into the biofilter tank, biofilter conditioning was carried out by adding $5 \mathrm{mg} / \mathrm{L}$ of ammonium chloride $\left(\mathrm{NH}_{4} \mathrm{Cl}\right)$ followed by daily measurement of ammonium $\left(\mathrm{NH}_{4}\right)$, nitrite $\left(\mathrm{NO}_{2}\right)$, and nitrate $\left(\mathrm{NO}_{3}\right)$ level. When ammonia and nitrite level have reached $0 \mathrm{mg} / \mathrm{L}, 10$ $\mathrm{mg} / \mathrm{L}$ ammonium chlorides were added. The biofilter was then ready for use once the ammonia and nitrite level have decreased to $0 \mathrm{mg} / \mathrm{L}$ once again.

\section{Experimental design}

The water in the culture tank is sterilized prior use by using 30 $\mathrm{mg} / \mathrm{L}$ of chlorine $(\mathrm{NaClO})$ for 1 day, then neutralized using $30 \mathrm{mg} / \mathrm{L}$ of sodium thiosulfate $\left(\mathrm{Na}_{2} \mathrm{~S}_{2} \mathrm{O}_{3}\right)$ for 1 day [14]. Before stocking, 8 days old shrimp post larvae (PL8) was gradually acclimatized from salinity level of $32 \mathrm{ppt}$ to $5 \mathrm{ppt}$ within 14 days. The shrimp was then cultured for 84 days at three different stocking shrimp density of $500 \mathrm{PL} / \mathrm{m}^{3}, 750 \mathrm{PL} /$ $\mathrm{m}^{3}$ and $1,000 \mathrm{PL} / \mathrm{m}^{3}$, each in four replicates. Poly- $B$-hydroxybutyrate (PHB)-supplemented diet at $0.5 \mathrm{~g} \mathrm{PHB} / \mathrm{kg}$ [11-13] was used as the sole shrimp diet in this study. RAS is operated continuously for 24 hours without water replacement, with the exception of water addition to compensate water evaporation that may gradually increase the salinity level of the culture water. Siphoning was conducted daily to remove most sediment from the culture tank as well as settlement tank $[15,16]$.

\section{Water quality parameters}

Water quality parameters including dissolved oxygen (DO), temperature, $\mathrm{pH}, \mathrm{NH}_{3}^{+}, \mathrm{NO}_{2}^{-}, \mathrm{NO}_{3}^{-}$and salinity level were measured biweekly during the 84 days of grow out period. DO level and temperature

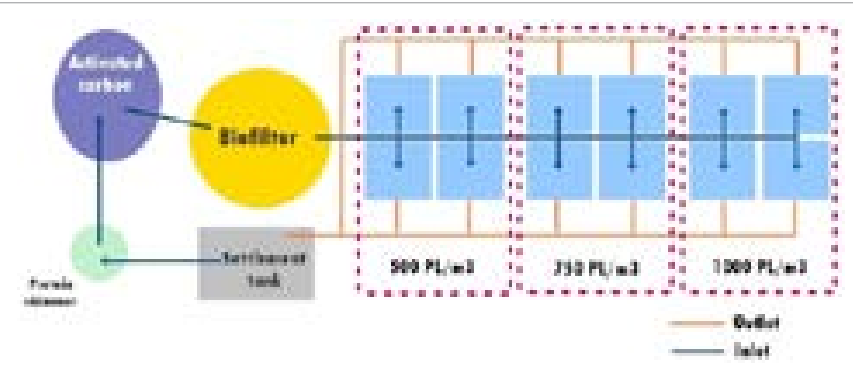

Figure 1: Scheme of recirculation aquaculture system (RAS) used in this study

\begin{tabular}{|c|c|c|c|}
\hline $\begin{array}{c}\text { Mean Body } \\
\text { Weight }\end{array}$ & Feeding Rate (\%) & Survival Rate (\%) & $\begin{array}{c}\text { Feeding Tray Monitoring } \\
\text { Intervals (hours) }\end{array}$ \\
\hline$<1$ & 10.0 & 100 & 3.5 \\
\hline $1-3$ & 8.0 & 98 & 3.5 \\
\hline $3-5$ & 6.0 & 96 & 2.5 \\
\hline $5-7$ & 5.0 & 94 & 2 \\
\hline $7-9$ & 4.0 & 92 & 2 \\
\hline
\end{tabular}

Table 1: Feed management applied during 84 days grow out period [15]. was measured using DO meter while $\mathrm{pH}$ level was measured by using $\mathrm{pH}$ meter. The $\mathrm{NH}_{4}^{+}, \mathrm{NO}_{2}^{-}$, and $\mathrm{NO}_{3}^{-}$levels were measured following Nessler, Diazotation, and Nitrate- $\mathrm{HCl}$ spectrophotometer method [17]. Salinity measurement was done using hand refractometer.

\section{Feeding regime and maintenance of the system}

Feeding management was done by calculation of daily feed amount based on estimation of mean body weight (MBW), survival estimation and feeding rate by following below equation:

Daily Feed $(\mathrm{g})=\mathrm{SD} \times \mathrm{MBW} \times \mathrm{FR} \times \mathrm{SR}$

where $\mathrm{SD}$ is the initial stocking density, $\mathrm{MBW}$ is the average mean body weight of shrimp (gram), SR is estimated survival rate (\%), and FR is feeding rate (\%). Detailed feeding regime used for this trial is presented in Table 1. Daily feeding frequency was four times a day at 09:00, 12:00, 16:00 and 21:00.

\section{Proximate analysis}

Proximate analysis was done at PT. Saraswanti Indo Genetech, Bogor, Indonesia, to determine the water, ash, total protein and lipid content, carbohydrates, and fatty acid content of the diet. Water content measured using drying method. The ash content was measured using heating at $600^{\circ} \mathrm{C}$ temperature and then weighed until constant [16]. Protein content was measured using Kjeldhal method while the lipid content was measured using Soxhlet method, fatty acid analysis was conducted by using gas chromatography, while carbohydrate content (including nitrogen free extract and crude fiber) was calculated by following this equation:

Carbohydrate level $(\%)=100 \%-($ moisture content + fat content + ash content + protein content)

\section{Biological parameters}

Sampling of shrimp was done every two weeks to evaluate the biological parameters including shrimp growth and survival. At the end of grow out period, the final shrimp total biomass was measured. The shrimp specific growth rate (SGR), survival as well as feeding efficiency in term of Feed Convention Ratio (FCR) were also calculated using the following formulas [18]:

Mean Body Weight $(\mathrm{gr})=\mathrm{W} / \Delta \mathrm{N}$

where $\mathrm{W}$ is weight shrimp and total shrimps

Survival $(\%)=\mathrm{N}_{\mathrm{t}} / \mathrm{N}_{\mathrm{o}} \times 100 \%$

where $\mathrm{N}_{0}$ is initial shrimp number, $\mathrm{N}_{\mathrm{t}}$ is final shrimp number, $\mathrm{t}$ is culture period (day)

Specific growth rate $(\%)=\left[\operatorname{Ln}\left(\mathrm{W}_{2}-\mathrm{W}_{1}\right) /\left(\mathrm{T}_{2}-\mathrm{T}_{1}\right) \times 100 \%\right\}$

where $\mathrm{W}_{1}$ is initial body weight $(\mathrm{g})$ at time $\mathrm{T}_{1}$ (day), and $\mathrm{W}_{2}$ is final body weight $(\mathrm{g})$ at the time $\mathrm{T}_{2}$ (day)

Feed Convention Ratio $(\mathrm{FCR})=\Sigma \mathrm{W}$ feed $/ \Delta \mathrm{W} \times 100 \%$

where $\Sigma \mathrm{W}$ feed is the total feed given during culture (g), and $\Delta \mathrm{W}$ is the total weight of shrimp in each tank (g)

Biomass $(\mathrm{gr})=$ Density $\times$ Average $\Delta \mathrm{W}$

where $\Delta \mathrm{W}$ are total of weight shrimps.

\section{Microbiological parameters}

Three shrimps were sampled from each replicate tank and pooled, 
Citation: Suantika G, Situmorang ML, Nurfathurahmi A, Taufik I, Aditiawati P, et al. (2018) Application of Indoor Recirculation Aquaculture System for White Shrimp (Litopenaeus vannamei) Growout Super-Intensive Culture at Low Salinity Condition. J Aquac Res Development 9: 530. doi: 10.4172/2155-9546.1000530

Page 3 of 6

rinsed and homogenized in $9 \mathrm{~g} / \mathrm{L} \mathrm{NaCl}$ sterile saline solutions. Subsequently, $100 \mu \mathrm{l}$ of each whole-body sample homogenate was plated on Nutrient Agar Seawater plates. The inoculated plates were incubated at $27 \pm 1^{\circ} \mathrm{C}$ for $24 \mathrm{~h}$ and the total number of viable heterotrophic bacteria was counted. One hundred microliters of each whole-body sample homogenate was also inoculated on Thiosulfate Citrate Bile Salts Sucrose agar plates to count the total number of Vibrio [19].

Pure bacterial samples then going through further identification process using molecular approach. Bacterial DNA extraction, polymerase chain reaction / PCR amplification, and bacterial rRNA $16 \mathrm{~S}$ gene sequencing were done at the Macrogen Inc., Korea, using commercial QiagenDNEasy blood and tissue kit, using 27F/1492R primer, using $785 \mathrm{~F} / 907 \mathrm{R}$ primer, respectively. Nucleotide Blast versus Genebank and National Centre for Biotechnology Information (NCBI) data was used for sequence homology search for the test sequences [19]. These results were validated by phylogenetic analysis performed by Maximum likelihood with 1000 bootstrap on MEGA 6.0.

The abundance of culturable bacteria, the proportion of each different species, as well as the Shannon-Wiener diversity index were calculated. Predominant culturable bacteria is determined when its proportion of abundance is higher than 10\% [20]. Subsequently, similarity dendogram was produced with UPGMA clustering method using Sorensen's coefficient with MVSP (Multi Variate Statistical Package) v32 software.

\section{Statistical analysis}

Comparison of shrimp survival, final MBW, total biomass, SGR, and FCR between treatment groups were done by using One-way Analysis of Variance analysis, where grouping of treatments was based on significant differences in mean values according to Duncan test (0.05) level of confidence.

\section{Result and Discussion}

\section{Bio-filter conditioning}

Conditioning of biofilter was performed in 10 days. Three days following addition of $5 \mathrm{mg} / \mathrm{L} \mathrm{NH}_{4} \mathrm{Cl}$, the $\mathrm{NH}_{4}^{+}$level had been decreased to $0 \mathrm{mg} / \mathrm{L}$, while $\mathrm{NO}_{2}{ }^{-}$was accumulated to $40 \mathrm{mg} / \mathrm{L}$. This indicated that at day 3 , only Ammonia Oxidizing Bacteria (AOB) had been activated.

\begin{tabular}{|c|c|c|c|c|}
\hline Parameters & $\mathbf{5 0 0} \mathbf{~ P L} / \mathbf{m}^{3}$ & $\mathbf{7 5 0} \mathbf{~ P L} / \mathbf{m}^{3}$ & $\mathbf{1 , 0 0 0 ~ P L / \mathbf { m } ^ { 3 }}$ & $\begin{array}{c}\text { Tolerance } \\
\text { level }\end{array}$ \\
\hline $\mathrm{DO}(\mathrm{mg} / \mathrm{L})$ & $5.95-8.24$ & $5.75-8.14$ & $5.67-8.32$ & $4-12[23]$ \\
\hline $\begin{array}{c}\text { Temperature } \\
\left({ }^{\circ} \mathrm{C}\right)\end{array}$ & $28.35-30.40$ & $28.20-30.38$ & $28.40-30.45$ & $26-30[23]$ \\
\hline $\mathrm{pH}$ & $6.80-8.00$ & $6.78-7.90$ & $6.70-7.90$ & $6.5-8.5[23]$ \\
\hline $\mathrm{NH}_{4}^{+}(\mathrm{mg} / \mathrm{L})$ & $0-0.52$ & $0-0.71$ & $0-0.67$ & $\leq 0.8[24]$ \\
\hline $\mathrm{NO}_{2}^{-}$(mg/L) & $0-0.53$ & $0-0.66$ & $0-0.64$ & $\leq 1.0[24]$ \\
\hline $\mathrm{NO}_{3}{ }^{-}(\mathrm{mg} / \mathrm{L})$ & $0-62.86$ & $0-66.12$ & $0-58.20$ & $<200[25]$ \\
\hline
\end{tabular}

Table 2: Physicochemical water quality parameters during 84 days of culture period.

\begin{tabular}{|c|c|}
\hline Nutrient parameters & Content (\% dry weight) \\
\hline Water & $5.77 \pm 0.63$ \\
\hline Ash & $10.65 \pm 0.11$ \\
\hline Total Lipid & $8.19 \pm 0.18$ \\
\hline Total Protein & $39.81 \pm 0.28$ \\
\hline Carbohydrate & $35.58 \pm 0.7$ \\
\hline
\end{tabular}

Table 3: Proximate analysis of shrimp diet.

\begin{tabular}{|c|c|c|c|}
\hline \multirow{2}{*}{ Parameters } & \multicolumn{3}{|c|}{ Density } \\
\hline & $500 \mathrm{PL} / \mathrm{m}^{3}$ & $750 \mathrm{PL} / \mathrm{m}^{3}$ & $1,000 \mathrm{PL} / \mathrm{m}^{3}$ \\
\hline Individual MBW(g) & $14.87 \pm 2.42^{\mathrm{a}}$ & $12.94 \pm 2.72^{b}$ & $11.32 \pm 3.60^{c}$ \\
\hline Total Biomass (g) & $520 \pm 17.53$ & $524 \pm 16.72$ & $499 \pm 27.54$ \\
\hline Survival Rate (\%) & $70 \pm 1.42^{a}$ & $53.67 \pm 4.16^{c}$ & $44 \pm 1.35^{b}$ \\
\hline $\begin{array}{c}\text { Feed Conversion } \\
\text { Ratio }\end{array}$ & $1.32 \pm 0.05^{\mathrm{a}}$ & $1.45 \pm 0.08^{b}$ & $2.05 \pm 0.12^{c}$ \\
\hline $\begin{array}{l}\text { Specific Growth } \\
\text { Rate }(\% B W / \text { day })\end{array}$ & $7.12 \pm 0.01^{\mathrm{a}}$ & $6.95 \pm 0.01^{\mathrm{b}}$ & $6.79 \pm 0.01^{c}$ \\
\hline
\end{tabular}

Table 4: Biological parameters during 84 days grow out period.

At day $4, \mathrm{NH}_{4} \mathrm{Cl}$ was added at a higher concentration of $10 \mathrm{mg} / \mathrm{L}$. At day 7 , the $\mathrm{NH}_{4}^{+}$level had been decreased to $0 \mathrm{mg} / \mathrm{L}$, while $\mathrm{NO}_{2}^{-}$level started to decrease and $\mathrm{NO}_{3}{ }^{-}$level was increased to $80 \mathrm{mg} / \mathrm{L}$. This indicated that both the AOB and Nitrite Oxidizing Bacteria (NOB) had been activated. The oxidation of $\mathrm{NH}_{4}^{+}$was faster than the oxidation of $\mathrm{NO}_{2}$ - due to the relatively faster growth of AOB ( $\pm 8 \mathrm{~h}$ ) compared to $\mathrm{NOB}\left( \pm 12 \mathrm{~h}\right.$ ) [21]. In addition to that, $\mathrm{NOB}$ needed the $\mathrm{NO}_{2}^{-}$as the oxidation product by $\mathrm{AOB}$ as its growth substrate. Following 10 days of biofilter conditioning period, the biofilter was ready to use as both $\mathrm{NH}_{4}^{+}$and $\mathrm{NO}_{2}^{-}$level had reached $0 \mathrm{mg} / \mathrm{L}$, while $\mathrm{NO}_{3}^{-}$level reached 100 $\mathrm{mg} / \mathrm{L}$.

\section{Water quality parameters}

Water quality management is one of primary consideration in any shrimp farming, particularly in systems with higher stocking density. It is suggested that degradation of water quality is detrimental to shrimp growth and survival. During 84 days of grow out period, all physicochemical water quality parameters in all shrimp densities were in tolerance level for shrimp culture (Table 2). This suggests that the continuous use of RAS can maintain stable water quality parameters even at high stocking densities of up to $1,000 \mathrm{PL} / \mathrm{m}^{3}$ with high organic load to the system. However, slightly lower inorganic nitrogen compounds of ammonia and nitrite were observed in the lowest shrimp density compared to the higher shrimp densities.

\section{Proximate analysis of shrimp diet}

Li et al. [22] suggested that properly high dietary lipid is able to improve the performance of L. vannamei at low salinity. It is reported by Zhu et al. [23] that $8 \%$ lipid diet allowed a slightly higher growth than $6 \%$ or $10 \%$ lipid diets in shrimp culture at low salinity of 2 psu. The diet used in this study contained $8.19 \pm 0.18 \%$ lipid, which was assumed to allow an optimum shrimp growth at low salinity of $5 \mathrm{ppt}[22,23]$. It is also suggested that an increase in dietary protein level in the diet of L. vannamei is necessary to increase the production of $L$. vannamei at low salinities, with a recommended $40 \%$ of dietary protein for shrimp culture to improve growth and health [22]. In this study, the diet was formulated to contain $40 \%$ total protein level and had the actual total protein level of $39.81 \pm 0.28 \%$ (Table 3 ). Overall, the diet used in this study supported a normal, if not optimal, shrimp growth at low salinity and that the resulted shrimp growth in this study using different high stocking density was not impaired by the low salinity level.

\section{Biological parameters}

During 84 days of grow out period, significant differences were found in final MBW, survival, SGR and FCR between shrimp groups with different density (Table 4). In term of growth, lower MBW were observed with the increasing shrimp density, where the lowest shrimp density of $500 \mathrm{PL} / \mathrm{m}^{3}$ produced shrimp with final MBW of $15 \mathrm{~g}$, while the higher densities resulted in lower final MBW of 11 to $13 \mathrm{~g}$. Similar to the growth parameter, a significantly higher survival (up to $70 \%$ ) was 
Citation: Suantika G, Situmorang ML, Nurfathurahmi A, Taufik I, Aditiawati P, et al. (2018) Application of Indoor Recirculation Aquaculture System for White Shrimp (Litopenaeus vannamei) Growout Super-Intensive Culture at Low Salinity Condition. J Aquac Res Development 9: 530. doi: 10.4172/2155-9546.1000530

Page 4 of 6

observed in the lowest shrimp density compared to the higher shrimp densities, where the highest shrimp density gained the lowest survival of only about $44 \%$. However, there was no significant difference in the total biomass produced between different shrimp density, with the total productivity value of up to $5.20 \mathrm{~kg} / \mathrm{m}^{3}, 5.24 \mathrm{~kg} / \mathrm{m}^{3}$, and $4.99 \mathrm{~kg} /$ $\mathrm{m}^{3}$ for the shrimp density of $500 \mathrm{PL} / \mathrm{m}^{3}, 750 \mathrm{PL} / \mathrm{m}^{3}$, and $1,000 \mathrm{PL} / \mathrm{m}^{3}$, respectively. In term of feed utilization efficiency, it was showed that the lowest FCR value of 1.32 was obtained in the lowest shrimp density and the values were increased with the increasing shrimp density of up to 2.05 in the $1,000 \mathrm{PL} / \mathrm{m}^{3}$ density.

In general, it can be suggested that the application of RAS system at the shrimp density of $500 \mathrm{PL} / \mathrm{m}^{3}$ can maintain good water quality during the 84 days of grow out period and allow high productivity of up to $5.20 \mathrm{~kg} / \mathrm{m}^{3}$ with high feed utilization efficiency and thus is highly potential to be implemented at the industrial level.

\section{Dynamic abundance of culturable bacteria}

The dynamic of the abundance of culturable bacteria in both culture water and shrimp during the culture period are shown in Table 5. In general, the number of culturable bacteria was calculated as much as $10^{3} \mathrm{CFU} / \mathrm{mL}$ in the culture water and $10^{5} \mathrm{CFU} / \mathrm{mL}$ in shrimp. The dynamic of the amount of bacteria present in water and shrimp depends on the organic content in the tank culture. Input of organic content can be derived from feeding and residual metabolism [24].

\section{Community structure of culturable bacteria}

A total of nine species of culturable bacteria in water samples and six species of culturable bacteria in shrimp samples were observed in different proportions (Figures 2 and 3). The identified bacteria were Staphylococcus saprophyticus, Shewanella amazonensis, Aeromonas caviae, Shewanella litorisediminis, Acinetobacterra dioresistens, Bowmanella pacifica, Bacillus altitudinis, Microbacterium kitamiense, and Pseudomonas aeruginosa.

In general, there was one bacterial species, S. litorisediminis, which was always observed with $>10 \%$ of abundance both in the culture water and shrimp in all treatment groups, especially until the $8^{\text {th }}$ week of culture period. Some species of Shewanella genus are considered as a good probiotic candidate as they exhibit antibacterial activity that may improve survival rate of shrimp culture [25]. The existed $S$. litorisediminis is suspected to be one of the indigenous bacteria in the shrimp, however very limited knowledge exists on the presence and role of S. litorisediminis in shrimp culture. Other species of Shewanella genus observed in this study is S. amazonensis, which has the ability to reduce heavy metals such as iron, manganese oxide, thiosulfate, and sulphur-containing substances [26].

During the last $1-2$ weeks of shrimp culture, a high relative abundance of $A$. radioresistens was observed in both shrimp and culture water. This bacterial species was reported to be one of the predominant strains with the $\mathrm{PHB}$ accumulating ability in a bacterial community from activated sludge [27]. The PHB supplementation in the shrimp diet used in this study may have opened niches for this bacterial species. P. aeruginosa is one of the bacteria that has the ability as a probiotic in shrimp. Research has been done that the feed given a mixture of $P$. aeruginosa can suppress the number of bacteria Vibrio sp. both in water and shrimp [28].

\section{Shannon-Wiener diversity index}

Diversity of species is determined by number of species (species richness) and relative abundance (species of evenness) [28]. Diversity

\begin{tabular}{|c|c|c|}
\hline Density & Culturable bacterial load in culture water (CFU/mL) & Culturable bacterial load in shrimp culture (CFU/mL) \\
\hline $500 \mathrm{PL} / \mathrm{m}^{3}$ & $8.30 \times 10^{2}-4.20 \times 10^{3}$ & $2.50 \times 10^{3}-3.49 \times 10^{5}$ \\
\hline $750 \mathrm{PL} / \mathrm{m}^{3}$ & $1.33 \times 10^{3}-5.81 \times 10^{3}$ & $5.50 \times 10^{3}-4.63 \times 10^{5}$ \\
\hline $1,000 \mathrm{PL} / \mathrm{m}^{3}$ & $2.17 \times 10^{3}-6.32 \times 10^{3}$ & $4.40 \times 10^{3}-3.36 \times 10^{5}$
\end{tabular}

Table 5: The abundance of culturable bacteria following 84 days of culture period.

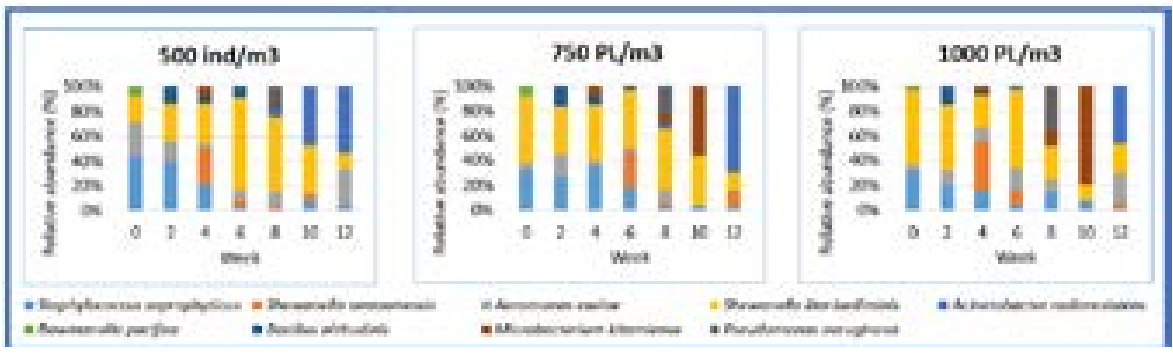

Figure 2: Relative abundance of culturable bacteria in culture water.

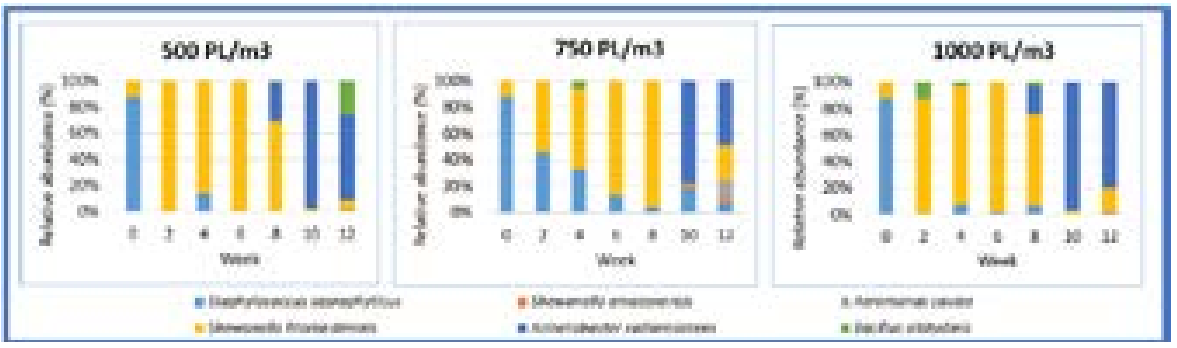

Figure 3: Relative abundance of culturable bacteria in shrimp culture. 
Citation: Suantika G, Situmorang ML, Nurfathurahmi A, Taufik I, Aditiawati P, et al. (2018) Application of Indoor Recirculation Aquaculture System for White Shrimp (Litopenaeus vannamei) Growout Super-Intensive Culture at Low Salinity Condition. J Aquac Res Development 9: 530. doi: 10.4172/2155-9546.1000530

Page 5 of 6

\begin{tabular}{|c|c|c|}
\hline Density & H' index of culture water & H' index of shrimp culture \\
\hline $500 \mathrm{PL} / \mathrm{m}^{3}$ & 1.621 & 1.113 \\
\hline $750 \mathrm{PL} / \mathrm{m}^{3}$ & 1.728 & 1.167 \\
\hline $1,000 \mathrm{PL} / \mathrm{m}^{3}$ & 1.819 & 1.002 \\
\hline
\end{tabular}

Table 6: Shannon-Wiener diversity index of water and shrimp culturable bacteria.

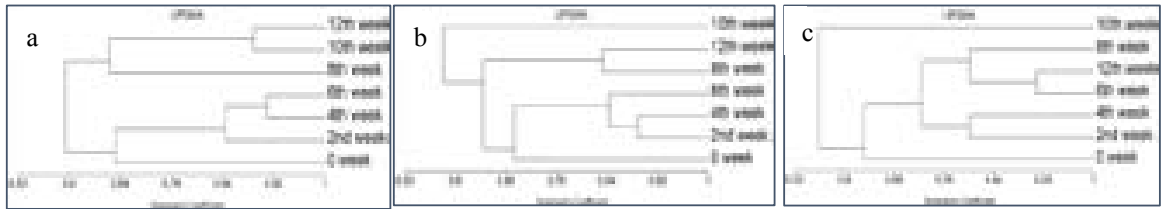

Figure 4: Dendogram of similarity of culturable bacteria in culture water at stocking density of (a) $500 \mathrm{PL} / \mathrm{m}^{3}$ (b) $750 \mathrm{PL} / \mathrm{m}^{3} \mathrm{and}(\mathrm{c}) 1,000 \mathrm{PL} / \mathrm{m}^{3}$.

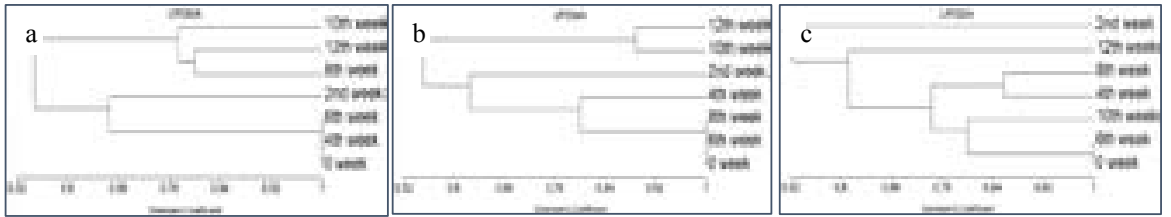

Figure 5: Dendogram of similarity of culturable bacteria in shrimp culture at stocking density of (a) $500 \mathrm{PL} / \mathrm{m}^{3}$ (b) $750 \mathrm{PL} / \mathrm{m}^{3}$ and (c) $1,000 \mathrm{PL} / \mathrm{m}^{3}$

can be affected by the competition between species within the habitat. The similarity of niches such as the physical or chemical conditions of the environment can trigger a species to adapt in a new environment $[29,30]$. The diversity index is considered low when the value less than one, medium if the value is between one to three, and high if higher than three [31]. The value of the diversity index in all three treatments with different stocking density is shown in Table 6 . The overall results suggested that the diversity index value of culturable bacteria in culture water and shrimp are both in the medium category.

\section{Sorensen similarity index}

Similarity analysis is often used to monitor the stability of culturable bacteria community structure. In this study, the values of the Sorensen similarity index were $>0.5$, suggesting similar community structures in both shrimp and culture water between all treatment groups [32]. Construction of dendogram of culturable bacteria in culture water in the $500 \mathrm{PL} / \mathrm{m}^{3}$ treatment group have two large groups (clade), while $750 \mathrm{PL} / \mathrm{m}^{3}$ treatment group have three large group with tenth week as an outgroup. Similarly, the 10th week occurred as the outgroup in the $1,000 \mathrm{PL} / \mathrm{m}^{3}$ treatment group. Dendogram of similarity culturable bacteria in water is shown in Figure 4. On the other hand, construction of dendogram in shrimp at the $500 \mathrm{PL} / \mathrm{m}^{3}$ treatment group has two large groups, while $750 \mathrm{PL} / \mathrm{m}^{3}$ treatment group has three large groups. Similarly, the $1,000 \mathrm{PL} / \mathrm{m}^{3}$ treatment group has three groups with the second week as an outgroup. Dendogram of similarity culturable bacteria in shrimp is shown in Figure 5. The overall results of this study suggested that the culturable bacterial community profile in both shrimp and culture water during 84 days of grow out period using RAS at low salinity were similar between different shrimp stocking density.

\section{Conclusion}

In this study, similar total productivity levels were observed in all treatment groups with different stocking density. All physicochemical water quality parameters in all treatment groups were in tolerance level for shrimp culture. Furthermore, stable community structure of culturable bacteria was also observed during the entire shrimp culture period even at high shrimp density of up to $1,000 \mathrm{PL} / \mathrm{m}^{3}$. Based on the overall results it is suggested that RAS can be applied for shrimp superintensive culture at the optimal density of $500 \mathrm{PL} / \mathrm{m}^{3}$ that allowed a high shrimp culture productivity of up to $5.20 \mathrm{~kg} / \mathrm{m}^{3}$ within 84 days grow out period.

\section{Acknowledgements}

This research was fully supported by Institut Teknologi Bandung under 'Program Penelitian, Pengabdian kepada Masyarakat, dan Inovasi (P3MI)' Research Grant in 2017. The authors would like to thank PT. Gapura Akua Kultiva, Bandung, Indonesia for the supply of bacteria house and nitrification bacteria culture, as well as PT. Suri Tani Pemuka, Indramayu, Indonesia for the supply of shrimp post-larvae used in this study.

\section{References}

1. Ratana C (2011) World small-scale fisheries: Contemporary visions. Eburon Uitgeverij BV: Delft, The Netherlands.

2. FAO (2016) The state of world fisheries and aquaculture. FAO: Rome, Italy.

3. Boyd CE, Clay JW (2002) Evaluation of Belize Aquaculture LTD: A super intensive shrimp aquaculture system. The World Bank, NACA, WWF and FAO Consortium.

4. Briggs M, Smith SF, Subasinghe R, Phillips M (2004) FAO Fisheries Technical Paper: Introduction and movement of two penaeid shrimps species in Asia and the Pacific. FAO: Rome, Italy. p: 476.

5. kharisma A, manan A (2012) kelimpahan bakteri vibrio sp. pada air pembesaran udang vanamei (litopenaeus vannamei) sebagai deteksi dini serangan penyakit vibriosis. Journal IImiah Perikanan dan Kelautan 4: 129-134.

6. Suantika G, Dhert P, Nurhudah M, Sorgeloos $P$ (2000) High-density production of rotifer Brachionus plicatilis in a recirculation system: consideration of water quality, zoo technical and nutritional aspects. Aquacult Eng 21: 201-214.

7. Defoirdt T, Halet D, Vervaeren H, Boon N, Van de Wiele T, et al. (2007) The bacterial storage compound of poly-b-hydrobutyrate protects Artemia fransiscana from pathogenic Vibrio campbellii. Environ Microbiol 9: 445-452.

8. Sui L, Cai J, Sun H, Wille M, Bossier P (2012) Effect of poly-beta-hydroxybutyrate on Chinese mitten crab, Eriocheir sinensis, larvae challenged with pathogenic Vibrio anguillarum. J Fish Dis 35: 359-364.

9. Thai TQ, Wille M, Garcia-Gonzalez L, Sorgeloos P, Bossier P, et al. (2014) Poly-ß-hydroxybutyrate content and dose of the bacterial carrier for Artemia enrichment determine the performance of giant freshwater prawn larvae. Appl Microbiol Biotechnol 98: 5205-5215. 
Citation: Suantika G, Situmorang ML, Nurfathurahmi A, Taufik I, Aditiawati P, et al. (2018) Application of Indoor Recirculation Aquaculture System for White Shrimp (Litopenaeus vannamei) Growout Super-Intensive Culture at Low Salinity Condition. J Aquac Res Development 9: 530. doi: 10.4172/2155-9546.1000530

Page 6 of 6

10. Laranja JL, Ludevese-Pascual GL, Amar EC, Sorgeloos $P$, Bossier $P$, et al. (2014) Poly- $\beta$-hydroxybutyrate (PHB) accumulating Bacillus spp. improve the survival, growth and robustness of Penaeus monodon (Fabricius, 1798) postlarvae. Vet Microbiol 173: 310-317.

11. Situmorang ML, De Schryver $P$, Dierckens K, Bossier $P$ (2016) Effect of poly- $\beta$ hydroxybutyrate on growth and disease resistance of Nile tilapia Oreochromis niloticus juveniles. Vet Microbiol 182: 44-49.

12. Nhan DT, Wille M, De Schryver $P$, Defoirdt T, Bossier $P$, et al. (2010) The effect of poly $\beta$-hydroxybutyrate on larviculture of the giant freshwater prawn Macrobrachium rosenbergii. Aquaculture 302: 76-81.

13. Duan $Y$, Zhang $Y$, Dong $H$, Zheng $X$, Wang $Y$, et al. (2017) Effect of dietary poly- $\beta$-hydroxybutyrate (PHB) on growth performance, intestinal health status and body composition of Pacific White Shrimp Litopenaeus vannamei (Boone, 1931). Fish Shell Immunol 60: 520-528.

14. Boon PJ, Holmes NTH, Raven PJ (2010) Developing standard approaches for recording and assesing river hydromophology: The role of European Committee for Standardization. Aquat Conserv 20: 555-561.

15. Tacon AG, Jory DE, Nunes AJP (2013) Shrimp feed management: Issues and perspectives. FAO Fisheries and Aquaculture Technical Paper 583: 481-488.

16. AOAC (1999) Official Methods of Analysis of (AOAC) International (16th edn). AOAC International, USA

17. American Public Health Association, American Water Works Association, Water Pollution Control Federation and Water Environment Federation (1999) Standard methods for the examination of water and wastewater. American Public Health Association.

18. Suantika G, Turendro OR, Situmorang ML (2017) Use of nitrifying bacteria for promoting freshwater prawn (macrobrachium rosenbergii) nursery phase in indoor system. J Fish Livest Prod 5: 228.

19. Suantika G, Situmorang ML, Aditiawati P, Khakim A, Suryanaray S, et al. (2017) Effect of red seaweed Kappaphycus alvarezii on growth, salinity stress tolerance and vibriosis resistance in shrimp litopenaeus vannamei hatchery. $J$ Fish Aquat Sci 12(3): 127-133.

20. Lin YC, Chen JC (2003) Acute toxicity of nitrite on litopenaeus vannamei boone juveniles at different salinity levels. Aquaculture 224: 193-201.

21. Suantika G, Pratiwi MI, Situmorang ML, Djohan YA, Muhammad H, et al. (2016)
Ammonium removal by nitrifying bacteria biofilm on limestone and bioball substrate established in freshwater trickling biofilter. Poult Fish Wildl Sci 4: 2.

22. Li E, Wang X, Chen K, Xu C, Qin JG, et al. (2017) Physiological change and nutritional requirement of Pacific white shrimp Litopenaeus vannamei at low salinity. Rev Aquacult 9: 57-75.

23. Zhu XZ, Liu YJ, Tian LX, Mai KS, Zheng SX, et al. (2010) Effects of dietary protein and lipid levels on growth and energy productive value of pacific white shrimp, Litopenaeus vannamei, at different salinities. Aquac Nutr 16: 392-399.

24. Suantika G, Lumbantoruan G, Muhammad H, Azizah FFN, Aditiawati P (2015) Performance of Zero Water Discharge (ZWD) System with nitrifying bacteria and microalgae chaetoceros calcitrans components in super intensive white shrimp (Litopenaeus vannamei) culture. J Aquac Res Development 6: 359.

25. Suantika G, Adiwati $P$, Indriani DA, Khotimah ZA (2013) The use of indigenous Probiotic Halomonas aquamarina and shewanella algae for white shrimp (Litopenaeus vannemai boone) hatchery productivity in zero water discharge system. J Aquac Res Development 4(5): 1-8.

26. Venkateswaran K, Dollhopf ME, Aller R, Stackebrandt E, Nealson KH (1998). Shewanella amazonensis sp. nov., A novel metal-reducing facultative anaerobe from Amazonian shelf muds. Int J Syst Bacteriol 48: 965-972.

27. Liu C, Wang H, Xing W (2013) Composition diversity and nutrition conditions for accumulation of poly-hydroxy-alkanoate (PHA) in a bacterial community from activated sludge. Appl Microbiol Biotechnol 97: 9377-9387.

28. Janakiram P, Veerendra KM, Jayasree L, Sivaprasad B (2014) Probiotic activity of $P$ seudomonas aeruginosa (PIC-4) isolated from Visakhapatnam Coast, Bay of Bengal, India, against Vibrio harveyi in Penaeus monodon. Int J Fish Aquat Stud 6: 199-207.

29. Molles MC (2015) Ecology: Concepts and applications. McGraw-Hill, Boston, UK.

30. Carriker MR (1967) Ecology of estuarine benthic invertebrates. In G.H. Lauff (ed) Estuaries Americans Association for Advantage of serene. Washington DC, USA.

31. Dykhuizen DE (1998) Why are there so many species of bacteria?. Antonie Leeuwenhoek: Santa Rosalia Revisited. 73: 25-33.

32. Yunasfi $P$ (2006) Decomposition of Avicennia marina leaf by bacteria and fungi at different salinity levels. Doctoral Dissertation, Institut Pertanian Bogor Bogor, Indonesia. 